\title{
Geopolitics and Contesting Identities in Shakespeare's The First Part of Henry VI
}

\author{
I-CHUN WANG
}

\begin{abstract}
Histories always deal with the construction of cities, announcements of new eras, and strategies of reformations; human history also shows that the bitter human experience of struggles, disputes and wars involve shifting identities or rivalries over territories. Among Shakespeare's war plays, The First Part of Henry VI is one of the most significant representations of the war between France and England; the play refers to the Treaty of Troyes, an AngloFrench Treaty in 1420, which recognizes Henry V as heir to the French throne, resulting in internal divisions and tremendous chaos in France. This play by Shakespeare refers to the intrigue, spatial contest, politics of kingship and spatial struggle between England and France. Calais had been an enclave of England in France before Henry V succeeded to the throne; securing Calais, Henry V, the warrior king of England, attempted to build up another enclave at Harfleur. With the Anglo-Burgundian alliance, the Dauphin Charles, and Joan of Arc faced two enemies, England and the Dukedom of Burgundy. England and Burgundy had been allies against France in the Hundred Years' War since 1415. Burgundy, because of its geographical location, is to play the key role in the tug of war between the two forces.

Geopolitics and contesting identities are two intertwining motifs in the First Part of Henry VI. Shakespeare portrays the conquest of France by England and represents diplomatic relations and shifting identities through geography and spatial politics as related to nationhood. This paper by examining the conflicts between France and England, will discuss geopolitics and contesting identities, the territorial disputes as well as spatial politics in an era when boundary politics was in flux.
\end{abstract}

Keywords: spatial politics; geopolitics; Joan of Arc; William Shakespeare; First Part of Henry VI; Hundred Years' War

On 17 July 1429, Joan of Arc (1412-1431) sent a letter to the Duke of Burgundy, Philip the Good (1396-1467), reminding him to attend the coronation of Charles VII to be held in the city of Rheims. Besides reminding the Duke that letters had been sent to him three weeks earlier, she took the opportunity to persuade the duke that he should not wage war any longer "in the holy kingdom of France" but should instead order his troops to withdraw. Joan further confirmed that the Duke of Burgundy himself "will never win a battle against 
Geopolitics and Contesting Identities in Shakespeare's The First Part of Henry VI

the loyal French," simply because "waging war in the holy kingdom of France" is equivalent to "fighting against King Jesus, King of Heaven and of all the world" . In this letter by Joan of Arc, a young woman of fifteen years, voiced her expectation that the French would be reunited under the crown. Joan of Arc's life story, marked with sieges of towns, campaigns, negotiations, advances and retreats of troops, represents the complicated geopolitics between France and England and the value of nationhood as well. As emblems of cultural traditions, wealth and political power, cities and towns are generally contested zones for military struggle. As this part of war history is represented by Shakespeare, the story that Joan of Arc was involved; it bespeaks geopolitics and the emerging identities of nationhood.

Joan of Arc, also called the Maid of Orleans, was born in Domremy, a town on the border of the provinces of Champagne and Lorraine of France (Sackville-West 1936: 24-28). Orleans is a city in northern France; its strategic position on the Loire River and symbolic significance had made itself a contested ground for the French and the English. As the place where in 1429 the French army led by Joan had their first major military victory of the Hundred Years' War, Orleans was represented by its inhabitants as a stronghold to resist the invaders. Orleans as well as the other towns and cities in the war zones represents levels of meanings during the political struggles for their nationhood.

Geopolitics is a term widely used for international studies. Geography is an important factor for identity formation, and geopolitics often intertwines with crossing boundaries. Henri Lefebvre, Stuart Hall, Georg Simmel, Anthony Giddens, and David Harvey all contend the meanings of spatial production, spatial practices as well as the process and result of special representation. Henri Lefebvre, a French Marxist philosopher and sociologist, contends that every society produces its own space but space eventually enshrines social relationships as well as state power, which Lefebvre refers as identities, relationships of opposition and contrasts, exchange and communications, etc. (1974: 220, 337). Doreen Massey, a British social scientist and geographer, stresses that space is not a flat surface, but instead, it is the product of interrelations, for territory or power. As she examines the Spanish conquest of Aztecs, she notices that before Hernán Cortés conquers the city of Aztecs, duplicitous negotiation, bloodshed, retreat and re-advance (Massey 2005:

For Joan of Arc's Letter to the Duke of Burgundy dated July 17, 1429: http:// archive.joan-of-arc.org/joanofarc_letter_july_17_1429.html. In this letter Joan of Arc requested the duke wage war no longer in the holy kingdom of France. 
WANG

4) are all involved with space and spatial politics, so that besides territory, identities, entities as well as the relations between them are all involved with power of geography (ibid. 10).

Geopolitical conflict testifies to the struggles in the history of the Hundred Years' War (1337-1453). Towards the construction of nationhood, Domremy emerges itself as a microcosm of the Anglo-French conflict. Domremy was a place of spatial complexity. This town situated on the border of imperial powers, witnessed people's tolerance and various representations of political powers. The diversity of sentiment engaged the inhabitants of each village in "perpetual altercation" (Turner 1825: 518). Andrew Lang in his The Red True Story Book notes the geopolitical conflicts enshrouding Domremy because of wars:

The two parties of Burgundy and Armagnac divided town from town and village from village. It was as in the days of the Douglas Wars in Scotland, when the very children took sides for Queen Mary and King James, and fought each other in the streets. Domremy was for the Armagnacs - that is, against the English and for the Dauphin, the son of the mad Charles VI. But at Maxey, on the Meuse, a village near Domremy, the people were all for Burgundy and the English. The boys of Domremy would go out and fight the Maxey boys with fists and sticks and stones. (1895: 27)

Charles T. Wood and Wilson-Smith observe that Joan of Arc must have experienced a series of identity crises, and geographically, linguistically and politically, Joan must have spent her childhood "on the edge" so as to develop her unique sense of identity $(2008: 133,2)$. Cultural geographer Hurriyet Babacan notes, geographic icons evoke emotions and senses of belongings, and places or communities enable associations between lived experiences, personal stories and memories that imply people's connections to locales (2006: 118); Abh Hua also suggests that individuals all long for home and belonging which involves the places that nurture emotion and values of cultural identities (2009: 138-140). Shakespeare's portrayal of Joan in the first part of Henry VI does not include her original identity as a peasant maid; as she met her father, she repudiates her father by saying "Thou art no father nor no friend of mine" (1973: IV.) Shakespeare seems to be extremely unsympathetic to the inexperienced warrior-maid from Domremy, a village long suffering from spatial politics, but the battles and sieges she fought marked her progress in the geopolitical wars between England and France.

Domremy, Joan of Arc's hometown, lies near one of the great linguistic divides in Europe. People in the north spoke German, Flemish or Dutch while in the west they spoke French. Geographically Domremy belonged to 
France but a part of it was within the territory of the Anglo-Burgundian party (Sackville-West 1936: 25). She stood on the stage of war already at the age of thirteen, but the dynastic conflict between England and France had been going on for seventy-five years. Joan was captured by the Burgundians and sold to the English; in Shakespeare, she is captured by the Duke of York, Richard Plantagenet, at the battle of Angiers (now Angers). After interrogations and formal accusations, Joan was burned at the stake, but her bravery inspired the French toward independence.

The issues of succession and territorial struggle are the core reasons for the Hundred Years' War between the two countries. The inception of the war can be traced back to 1337 when King Philip VI of France confiscated Aquitaine, an area of France under the control of England, which extends from Normandy, through Maine, Anjou, Touraine and Poitou to the duchy of Aquitaine (Allmand 1989: 7). Edward III, King of England and, formally, a vassal of Philip VI of France, responded by challenging Philip's right to the throne through his identity as the grandson of Philip IV through his mother's bloodline, initiating incessant warfare between the two countries. With Charles VI's intermittent psychosis and the feud between the French royal family (the Armagnacs) and the house of Burgundy, in 1415 Henry V of England took the advantage to launch an invasion and defeated the French troops at the Battle of Agincourt. The Duchy of Burgundy as a fief of the King of France was a political entity, independent from Paris. John the Fearless, Duke of Burgundy, serving the regent during the insanity of the French King, embraced a diplomatic strategy and political interests that favored an agreement with the English. The aftermath of the war included the notorious Treaty of Troyes and the marriage of Henry V and Catherine of Valois, which resulted in various examples of English kings claiming the French throne. This treaty recognized Henry $\mathrm{V}$ as heir to the French throne, resulting in internal divisions and tremendous chaos in France and the tug of war between England and France, which eventually marked its end with the decisive French victory at the Battle of Castillon in 1453. In world literature, geography and territories are the terms oftentimes intertwined with intrigue, spatial contest, the politics of kingship, spatial struggle and national spirits. Shakespeare's Henry VI Trilogy is a dramatic work dealing with early modern human geography, which represents not merely geographical space, such as the loss of England's French territories, but also the bitter human experience of struggle, disputes and wars that involve shifting identities or rivalries. Shakespeare portrays the conquest of France by England, diplomatic relations and shifting identities through geography and spatial politics, as well as cities besieged and the attitude of the duke of 
Burgundy. This study, by examining territorial conflicts between France and England as represented in The First Part of Henry VI, explores territorial disputes and spatial politics in an era when boundary politics was fluid.

Shakespeare's Henry VI, Part One begins with the scene at Westminster Abbey where the eulogy for Henry $\mathrm{V}$ as well as the funeral procession ritualizes the image of the respected warrior king; however, the funeral also displays the scheming politicians whose plans forecast disastrous battles during the reign of the infant king. In Act One, Scene One, the messenger interrupts the sorrowful atmosphere with the message that the French have recaptured several towns that Henry $\mathrm{V}$ had conquered in his previous battles:

Sad tidings bring I to you out of France,

Of loss, of slaughter, and discomfiture:

Guienne, Champaigne, Rheims, Orleans,

Paris, Guysors, Poictiers, have been all quite lost. (I.i. 57-60)

The towns that the messenger reported refer to the northeastern and the southwestern regions of France. Guienne, as the Messenger mentions, was also called Guyenne, a region situated in the southwestern part of France, facing the Atlantic Ocean. When Eleanor of Aquitaine married King Henry II of England, this area became an English possession. As Thomas A. Du Bois suggests, the Duchy of Aquitaine was one of the strongholds of France, and a place renowned for wine, an important resource in medieval times ${ }^{2}$. Edward III, his son, Edward, Prince of Wales, and Henry V of England all ruled over the area. Rheims was a center of intellectual culture and its Cathedral of NotreDame de Rheims was the place of coronation of the kings of France; with the Treaty of Troyes, Rheims was eventually ceded to the English. The siege of Rheims was recurrent until 1429, under the influence of Joan of Arc, when French patriots raised it and crowned Charles VII as the king of France. Paris, the location of the royal palace, was one of the few significant financial centers in medieval Europe; during the sieges by Henry V, the French royal parliament was relocated to Poictiers (Poitiers) in 1418, totally 183 miles from Paris ${ }^{3}$. Paris, which was retaken by the Burgundians in 1418, would become another political center for the Anglo-Burgundian regime.

As Deborah Cowen contends, "being political is always a matter of being, becoming, in place and through space” (2008: 1). Before 1428 when Joan of Arc

For the Duchy of Aquitaine, see DuBois.

3 For Poictiers, see World Heritage Encyclopedia, http://www.worldheritage.org/articles/ Poitiers. 
Geopolitics and Contesting Identities in Shakespeare's The First Part of Henry VI

laid her petition before the commander of the town of Vaucouleurs, the alliance between England and Burgundy and the truce between Brittany and England had lasted for some years. However, when Paris and Rouen were on the brink of war because of the civil war, the Pro-Burgundian citizens of Paris opened the gates to John the Fearless in 1418 (Vaughan 2002a: 263). His most notorious act was that, when Henry V was staging an attack on Paris, the Duke of Burgundy "hindered the government from taking any steps for the defense of Normandy" (Mortimer 1763: 16). With the marriage between Anne of Burgundy and the Duke of Bedford, this political move, negating the ties among the French partisans, resulted in at least two unexpected disasters as they were termed by Guy Llewelyn Thompson: the Parisians fell under English rule and the AngloBurgundian regime destabilized French identity for half a century (1991: 1-8).

Mapping or topographical image-making features in a number of Shakespeare's plays. Although G. K. Hunter suggests that geographical exactitude was not a part of the literary tradition (1978: 171) yet, through representing space and topography, Shakespeare's cities, towns and fortresses in the Henriad tetralogy demonstrate not only the interplay of military operations and the struggle for power but also spatialized cultural identities. In the First Part of Henry VI especially, in the spatial distance from London, the imperial center of England, of the invaded cities and towns in France, Shakespeare represents a country divided through spatial images and configurations. The decisive cause of English rule over Normandy during the reign of Charles VI, lies in the attitude of the Dukes of Burgundy, first that of John the Fearless and then that of Philip the Good; the former was regent for Charles VI of France while the latter chose to side with England, not expecting in 1429 that, with the help of Joan of Arc, Charles would be crowned king, which suggests treason on the part of Philip. The duchy of Burgundy, located in the east central France, was a wealthy fief of the French crown; its territory stretched from Troyes and Lyons to the north and south. As for Calais, together with the other towns, it was an English possession from 1360 to 1558 because of the Treaty of Bretigny. It became not merely England's commercial center on the European continent but also a military stronghold on the French channel coast.

Henry V (1386-1422) is notable as a warrior king in the history of France. He succeeded to the throne of England in 1413 at the age of 26, but in the next year Henry took advantage of France's civil war between the House of Orleans (the Armagnacs) and the House of Burgundy. As regent of France on behalf of King Charles of France, John the Fearless claimed himself as a protector of the King during his mental illness. Secret agreements with Duke John (the Fearless) of Burgundy (1371-1419) were arranged (Haigh 2000: 121). When Burgundy was busy at war with his opponents, Henry invaded Normandy 
WANG

with less opposition from the local French forces (ibid. 121). Henry landed on the north bank of the Seine estuary on Aug 16, 1415 and besieged the nearby fortress town of Harfleur and in three years' time, an extensive part of Normandy was conquered, which includes its principal cities, Rouen and Rheims, and towards its east, Crecy and Calais. Burgundy did not participate in the Battle of Agincourt, nor the Norman Campaign to defend France against Henry V, King of England (ibid. 68). Following the assassination of John the Fearless, Duke of Burgundy, Charles VI's cousin and Regent in 1419, the recurrent madness of Charles, and great loss during the war, in 1420, the Treaty of Troyes was signed. The Queen agreed to the marriage of Henry V to Princess Catherine Valois and Charles VI agreed to give the French crown to his son-inlaw, Henry of England and Henry's heirs. This shameful Anglo-French treaty signifies a ratified agreement which disinherited the French Dauphine. This treaty not only foreshadowed more military challenges to come across the channel but also reinforced the relationship between England and Burgundy. Although Dauphin Charles claimed the throne of France upon the death of his father in 1422, Burgundy had already become an English ally. The Duchy of the English king in France and Anglo-Burgundian-controlled territory were already a considerable part of the territory attributed to France.

Shakespeare's The First Part of Henry VI starts with the funeral of King Henry $\mathrm{V}$, but the geopolitical positions of Paris and Rheims are the two most important cities elaborated in this play. The geopolitical tensions are highlighted by the imperial expansion of England and its Continental campaign. Border crossing is represented in terms of space through the Anglo-French military conflict and power struggle, Throughout the whole play, Paris and Rheims are the contesting zones; the other battlefields include Orleans, Rouen, Bordeaux, Anger (Anjou) and Calais, which symbolically represent the extensive sufferings of war by the inhabitants. Furthermore, the naming of all these towns and cities helps reinforce the idea of the extensive losses of lives and territories, as well as the question of cultural identities and political antagonisms between France and England. As the messenger reports in anxiety at the very beginning of the play, Charles VII of Valois' coronation as French King has been held in Rheims. These geographical locations signify the import of the power struggle:

Lords, view these letters full of bad mischance.

France is revolted from the English quite,

Except some petty towns of no import.

The Dauphin Charles is crowned king of Rheims;

The Bastard of Orleans with him is join'd;

Reignier, Duke of Anjou, doth take his part;

The Duke of Alencon flieth to his side. (Shakespeare 1973, I. i. 90-95) 
Rheims was located in the Alsace-Champagne-Ardenne-Lorraine region; the Treaty of Troyes had ceded it to the English. According to Robin Neilands, Rheims was best known as the coronation site during the medieval and early modern period; the coronation at Rheims reinforces "Charles's standing in France" because "the young Henry VI of England and France was still uncrowned" (1990: 263). Probably with an aim to settle the disputed succession to the throne, Charles' coronation at Rheims had cultural and political significance. Now that England's rival Dauphin Charles had secured his title, one of the most important matters for Bedford to settle was to find a place to declare the legality of Henry VI as the king of France, so Paris was the target for them to aim for. Nicolas Menin, an eighteenth-century scholar, describes the process and ceremony of coronation as requiring invitation letters to officers, ambassadors, princes of the blood, peers, prelates, nobles of the kingdom and ministers of foreign princes as well. The coronation was a significant event, in fact a spectacle; streets were adorned and triumphal arches established. Through a series of stages, the archbishop crowned him king, blessed and anointed him with sacred oil, and issued a proclamation on behalf of the new king (1772: 105-146). From Act Three to Act Four, Charles keeps mentioning that the Parisians have become warlike, so it seems that there is hope that the French will win. However, Joan la Prucelle observes the troops of England marching toward Paris, a city that the English could not have missed:

Hark! by the sound of drum you may perceive

Their powers are marching unto Paris-ward. (Shakespeare 1973, III. iii. 29-30)

To Joan, liberating the French requires winning over the Duke of Burgundy, especially because of Burgundy's alliance with England. The coronation of Charles at Rheims signifies the proclamation of an identity, a tradition and the recognition of sovereignty. These ritualized cultural and political elements helped shape the identities of the two countries.

Shakespeare represents the military contests between France and England through geographical sites of cultural and political significance. In Act Three, the battlefield turns out to be Rouen, when Bedford and Burgundy are within the castle. Joan and her men therefore disguise themselves as peasants, sneaking into the city to signal Charles to launch a surprise attack against the English. Joan la Pucelle also takes the opportunity to persuade Burgundy to leave Talbot. She calls Burgundy the "undoubted hope of France," capable of turning the "edged sword another way," to wash away France's stained spots (Shakespeare 1973, III. iii. 29-30, 56-57): 
Look on thy country, look on fertile France,

And see the cities and the towns defaced

By wasting ruin of the cruel foe $[. .$.

$[\ldots]$

As looks the mother on her lowly babe

When death doth close his tender dying eyes,

See, see the pining malady of France;

Behold the wounds, the most unnatural wounds. (Shakespeare 1973, III. iii. 44-50)

Quite a few scenes of the play involve the siege of Rouen and defense and the rescue of Orleans as well. The sieges and defense reveal the construction of national identity or as Benedict Anderson terms it, the collective identity. One of the most touching scenes revealing the French spirit is found in the first Act where a Master Gunner is teaching his son to watch over the City of Orleans against English invasion. Their conversation reveals that the devoted French Master Gunner has spent the last three days watching over the movement of the English camps: "Thou know'st how Orleans is besieged,/ And how the English have the suburbs won." His son responds, "In yonder tower, to overpeer the city, / And thence discover how with most advantage/ They may vex us with shot, or with assault" (Shakespeare 1973, I. iv. 2-13). Ironically, Salisbury is mortally wounded and Gargrave dies under fire. The Gunner and his son represent the voices of Orleans and the Master Gunner's gesture of bequeathing his mission of protecting Orleans is ritualized in the first Act of the play. The relief of Orleans by Joan la Pucelle involves several military actions that are roughly called the French Loire Campaign. Being a natural bridgehead over the Loire Valley, gateway to the entire south, Orleans has long been the target of military confrontations during the Hundred Years' War. As David Nicolle suggests, with English troops guarding Paris, the loss of Orleans would suggest the loss of the Loire valley (2001: 28). The delivery of Orleans in 1429 is a turning point in the Hundred Years' War, but soon after Joan was captured at Compiegne ${ }^{4}$, and the French were drastically challenged in terms of pressure to change their identity.

\footnotetext{
4 Joan was captured at Compiegne. According to Pierre Beaudry's brilliant essay and translation from Gabriel Hanotaux: "The affair starts with a pact signed in Amiens on April 17, 1423 where a rapprochement took place among the Duke of Burgundy, the Duke of Bedford, the Duke of Bretagne, the Comte of Foix and Richemont. Queen Yolande and the Duke of Savoy were brought into the secret of this arrangement through the Duke of Burgundy. That was a formidable alliance. These powerful allies had come together because they were hoping to get a parcel of what remained of the power and the substance of the kingdom of France." (Hanotaux 1911, quoted in Beaudry 2017.)
} 
Geopolitics and Contesting Identities in Shakespeare's The First Part of Henry VI

Shakespeare's The First Part of Henry VI is a drama that contrasts the embodiment of patriotic heroism in Lord John Talbot and the mysterious and subversive power in the maid of Orleans. The reinforcement of the encounter takes place in the scene at Orleans. Shakespeare's Joan la Pucelle involves the mysterious and supernatural before the English, while John Talbot is the epitome of the medieval soldier with his chivalrous spirit and nobility while most of the English nobles are quarrelling and plotting amongst themselves for benefits. As General of the English troops, he has the power to intimidate the French and the courage to fight for his country. Joan la Pucelle, in the depiction of Shakespeare, is presented as a witch deserving of execution in Act Five. Talbot and Joan cross swords and take turns winning and losing the battles; resenting la Pucelle's craftiness, Talbot feels especially frustrated when la Pucelle is able to break into Orleans to rescue her people from famine. However, in Act Four, Scene Five, the battle of Bordeaux witnesses the deaths of John Talbot and his son. Talbot is aware that French troops outnumber his own soldiers, and that there are no other English troops to rescue him. Although he requests reinforcements, there are none. He laments, "Soldiers, adieu! I have what I would have,/ Now my old arms are young John Talbot's grave" (Shakespeare 1973, IV. vii, 31-32).

Geopolitical factors continue to represent the political machinations involved with French territories and the pivotal point seems to be the decision of Burgundy. In Act Four, Scene One, to the surprise of Henry VI, Falstaff returns with a letter from Burgundy, Philip the Good, which announces Burgundy's alliance with Charles:

I have, upon especial cause,

Moved with compassion of my country's wreck,

Together with the pitiful complaints

Of such as your oppression feeds upon,

Forsaken your pernicious faction

And join'd with Charles, the rightful King of France. (Shakespeare 1973, 55-60)

The powerful Duke, Philip the Good, as represented by Shakespeare, has been regarded as a duplicitous politician. In 1420, Charles VI conferred on Philip the towns of Peronne, Roye and Mondidier and surrounding territories, but Bedford's diplomatic strategy of the Anglo-Burgundian alliance also included signing over the military spoils to Philip the Good (Vaughan 2002b: 391). In 1424 only, they included Auxerre, Macon and Bar-sur-Seine (ibid. 18). As Barbara Hanawalt and Michal Kobialka contend, people create uses for space and space will influence the behavior of those who define it and occupy 
WANG

it (2000: x). Incited by the Anglo-French conflict, Philip the Good turned into a collector of lands, acquiring Alsace, Holland, Hainaut, Friesland and Brabant, etc., and stretched his geographical expansion to Flanders (Vaughan 2002b: 73). In the depiction of Shakespeare, Joan has to face her own destiny. Joan's trial and tragic execution by burning on the false charge of witchcraft and her claims to unite the French territory are put to the test. As for Philip the Good, his detachment from England was not achieved until he signed the Treaty of Arras with Charles VII (Vaughan 2002b: 113). Philip looked to his own interests in his expansion of territory and diplomatic priority; as seen in his sieges of Calais and Paris in 1435 and 1436, respectively, the two most important English enclaves on the territory of France.

Shakespeare's sense of geopolitical factors and spatial identities involves not merely cross-channel relations between England and France but also the multiple issues as related to territorial contests. The First Part of Henry VI refers to the intrigue, spatial contest, politics of kingship and spatial struggle between England and France and exemplifies the long struggle for territorial justification. Besides the prowess of soldiers, inevitable bloodshed in the military conflicts, and the core themes of French resistance and the animosity of the English toward Joan of Arc, Shakespeare represents or implies geographical location, such as cities were won or lost, battles of resistance and conquest, the coronation of Charles the Dauphin, and the marriage arranged between Henry VI of England and the captured princess, Margaret of Anjou. It seems that, other than military actions, ceding territories and taking a bride from invaded states were alternative forms of resolution of political negotiations, which entailed more geographical compression or expansion. Towards the end of the play, with the capture of Margaret Anjou, the Duke of Suffolk recommends:

Yes, lord, her father is a king,

The King of Naples and Jerusalem;

And of such great authority in France

As his alliance will confirm our peace

And keep the Frenchmen in allegiance. (Shakespeare 1973, V.v. 39-43)

Henry replies, "That Lady Margaret do vouchsafe to come / To cross the seas to England and be crown'd / King Henry's faithful and anointed queen” (Shakespeare 1973, V. v. 89-91). Henry VI thus promises that the coronation of his bride, Margaret of Anjou, will be held in England, leading to geographical and political musings among his courtiers regarding Margaret's father, René of Anjou. 
Geopolitics and Contesting Identities in Shakespeare's The First Part of Henry VI

Although Henry VI of England attempts to settle more resolutions in London, his command center for his claim to the French throne, the Duke of York foresees "the utter loss of the realm of France" (Shakespeare 1973, V. iv). York is partially right, since a lot of towns and cities, namely, Cherbourg in Normandy, the Pro-English Gascony and many others, remain English-ruled enclaves in France for a short period of time (Nicolle 2013: 26-45). Calais will stand as an English enclave at the northern end of France till 1558 (Rose 2008: 1-10). In The First Part of Henry VI, Shakespeare presents the period from Henry V's military border crossing to Suffolk's delivery of his captive, Margaret of Anjou, to the king and the request of the return of Anjou and Maine to Reignier. With the Anglo-Burgundian alliance, the Dauphin Charles' coronation and Joan of Arc's defense of her kingdom against two enemies, England and the Dukedom of Burgundy, Shakespeare parallels sufferings, cruelties, devotion and betrayal with the extensive topography of battlefields, shifting borders and allegiances and alliances, and contesting identities in the geopolitical history of the Hundred Years' War.

\author{
I-Chun Wang \\ ichunwang@kmu.edu.tw;icwang@mail.nsysu.edu.tw \\ Kaohsiung Medical University and \\ National Sun Yat-sen University \\ TAIWAN
}

\title{
Bibliography
}

Allmand, C. T. 1989. The Hundred Years War: England and France at War c. 1300-c. 1450. Cambridge: Cambridge UP.

Babacan, H. 2006. Locating Identity: Sense of Space, Place and Belonging. - International Journal of Diversity in Organisations, Communities and Nations, 5.5,113124.

Beaudry, P. 2017. Joan of Arc's Battle against the Lotharingan Empire. - http:// amatterofmind.org/Pierres_PDFs/HISTORY\%202/BOOK_I/25._JOAN OF_ARC'S_BATTLE_AGAINST_THE_LOTHARINGIAN_EMPIRE.pdf (04.02.2017).

Cowen, D. 2008. Introduction: The Politics of War, Citizenship, Territory. - War, Citizenship, Territory. London: Routledge, 1-32.

DuBois, T. A. Chapter 34. Paris [November 18, 1347]. Cultural Explanations. - Pilgrim Reindeer in Pisa, 1348, http://tadubois.com/Bavlos/Bavlos-ch34_cultural_ explanations.htm (01.03.2019).

Haigh, C. 2000. The Cambridge Historical Encyclopedia of Great Britain and Ireland. Cambridge: Cambridge UP. 
WANG

Hanawalt, B.; Kobialka, M. 2000. Introduction. - Medieval Practices of Space (Medieval Cultures). Minneapolis: U of Minnesota Press, 9-18.

Joan of Arc's Letter to the Duke of Burgundy (July 17, 1429), http://archive.joan-of-arc. org/joanofarc_letter_july_17_1429.html (01.03.2019).

Lefebvre, H. 1974. The Production of Space. Transl. by Donald Nicholson-Smith. Cambridge, Mass: Blackwell.

Hua, A. 2009. 'What We All Long for': Memory, Trauma and Emotional Geographies. - M. Smith, J. Davidson, L. Cameron, L. Bondi, eds., Emotion, Place and Culture. New York: Routledge, 135-148.

Hunt, Maurice. 2002. The Politics of Vision in Shakespeare's "1 Henry VI". - South Central Review, 19, 1, 76-101.

Hunter, G. K.1978. Elizabethans and Foreigners. - Dramatic Identities and Cultural Tradition. Liverpool: Liverpool UP, 85-112.

Lang, A. 1895. The Red True Story Book. London: Longmans, Green, and Co.

Massey, D. 2005. For Space. London: Sage.

Menin, N. 1772. A Description of the Coronation of the Kings and Queens of France. London: S. Hooper.

Mortimer, T. 1763. A New History of England from Earliest Accounts of Britain to the Ratification of the Peace of Versailles. London: J. Wilson.

Neilands, R. 1990. The Hundred Years War. London: Routledge.

Nicolle, D. 2001. Orleans 1429: France Turns the Tide. Oxford: Osprey.

Nicolle, D. 2013. The Fall of English France 1449-1453. Oxford: Osprey.

Poitiers. - World Heritage Encyclopedia. http://www.worldheritage.org/articles/ Poitiers (01.03.2019).

Rose, S. 2008. Calais: An English Town in France: 1347-1558. Woodbridge: Boydell and Brewer.

Sackville-West, V. 1936. Saint Joan of Arc. New York: Grove.

Semenza, G. M. C. 2001. Sport, War, and Contest. - Renaissance Quarterly, 54, 4, 125-1272.

Shakespeare, W. 1973. The First Part of Henry the Sixth. - G. Blakemore Evans, H. Levin et al., eds., The Riverside Shakespeare. New York: Houghton Mifflin, 596628.

Turner, S. 1825. The History of England during the Middle Ages. Vol. 2.London: Longman.

Thompson, G. L. 1991. Paris and Its People under English Rule: the Anglo-Burgundian Regime, 1420-26. Oxford: Clarendon P.

Vaughan, Richard. 2002a. John the Fearless: The Growth of Burgundian Power. Vol 2. [First published in 1973.] Suffolk: Boydell.

Vaughan, R. 2002b. Philip the Good: The Apogee of Burgundy. Vol 3. [First published in 1970.] Suffolk: Boydell.

Wilson-Smith, T. 2006. Joan of Arc: Maid, Myth and Mystery. Stroud, Gloucestershire: The History Press.

Wood, C. T. 1988. Joan of Arc and Richard III: Sex, Saints, and Government in the Middle Ages. Oxford: Oxford UP. 